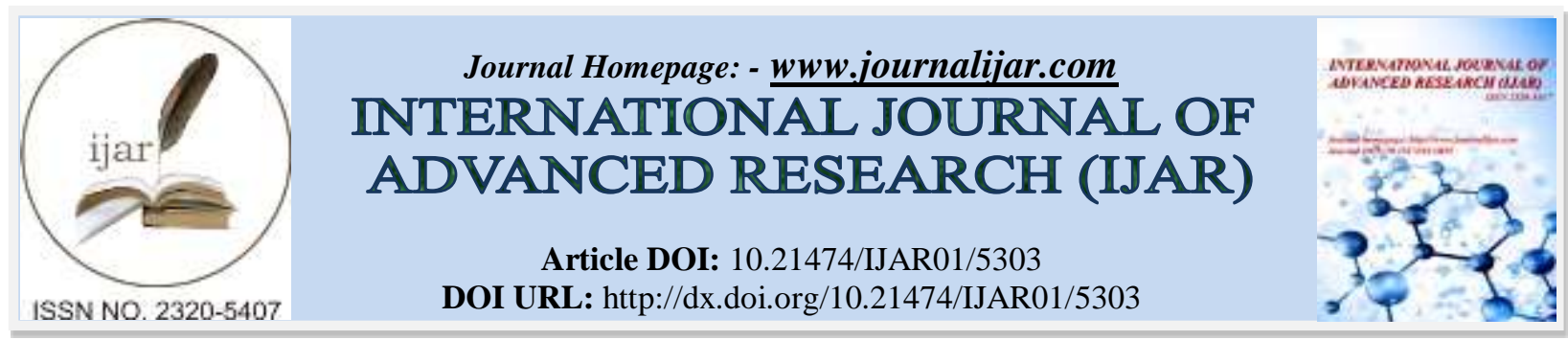

RESEARCH ARTICLE

\title{
SUCCESSFUL EXPLANT RESPONSE OF Aloe barbadensis THROUGH MICROPROPAGATION FOR THE RAPID REGENERATION OF PLANTS.
}

\section{Aarthi Pugazhendhi ${ }^{1}$ and D. Satish Sekar ${ }^{2}$.}

1. Research Scholar, Periyar University, Salem, Tamil Nadu, India.

2. Associate Professor, Department of Biotechnology, PEE GEE College of Arts \& Science, Dharmapuri, Tamil Nadu.

\section{Manuscript Info}

Manuscript History

Received: 02 July 2017

Final Accepted: 04 August 2017

Published: September 2017

Key words:-

Aloe vera, Tissue culture,

Phytochemicals, Antioxidant property,

Organic fertilizer.

\begin{abstract}
There is considerable use of $A$. barbadensis in folk medicine in the southernmost United States, and some cosmetics and patent medicines generally found on the market are prepared from the gel in the leaves and from the juice. There is a lack of production of Aloe leaf to meet the industry demand and so it is necessary to undertake large scale cultivation of Aloe. Large scale propagation can be standardized through Tissue culture where the yield is more and highly free from diseases, pests. Poor natural propagation by means of axillary shoots and the presence of male sterility are the two major barriers in rapid propagation of $A$. barbadensis. This plant is highly nutritive which contains the phytochemicals and antioxidants used for therapeutic purposes. In this study, the production and development of the medicinal plant was done through tissue culture and the phytochemical compounds and antioxidants for therapeutic use will be identified after its hardening. Phytochemical studies and the antioxidant activity tests from the hardened leaves prove the medicinal property in Aloe vera and the Aloe vera gel obtained can be used as an organic fertilizer for the enrichment of plants. This implies that the tissue culture method serves as the best time consuming method for obtaining Aloe vera as a multipurposeful plant.
\end{abstract}

Copy Right, IJAR, 2017,. All rights reserved.

\section{Introduction:-}

Aloe barbadensis is one of the richest sources of health for human beings coming from nature. It has been grown as an ornamental plant widely. Products of the plant are used in the treatment of various ailments. Aloe vera is a unique plant which is a rich source of many chemical compounds and plays an important role in the international market (Dwivedi N.K et al., 2014).

\section{Active Ingredients:-}

Fresh aloe juice/gel from the inner leaf parenchyma contains $96 \%$ water, polysaccharides (mucilage) consisting mainly of D-glucose and D-mannose, tannins, steroids, enzymes, plant hormones, amino acids, vitamins, minerals, and a small amount of barbaloin. The dried latex from the superficial pericycle cells contains at least $28 \%$ hydroxyanthracene, calculated as anhydrous barbaloin, which is a mixture of aloinAand aloin B, resin and saponins.The enzymes in aloe are destroyed at temperatures above $70^{\circ} \mathrm{C}$. Fresh leaves and carefully made extracts 
therefore have the greatest effect, while heated, powdered dry extracts have much weaker or even negative effects. The ingredients in Aloe can be grouped into the following categories: Vitamins, Minerals, Sugars, Enzymes, Lignins, Amino Acids, Anthraquinones, Saponins, Fatty Acids, Salicylic Acid (Eufrocinio C. Marfori and Aubrey B. Malasa, 2005).

\section{Key Actions:-}

It heals wounds, is emollient and stimulates secretions of bile. Aloe is laxative. Gels of different strengths, oil extracts, leaf concentrates, and powders are available. South African Aloe gives quality gel. The processed gel is used indifferent preparations such as Drugs, Cosmetics, Soft drinks, Food Preparations, Moisturizers, Healthcare products (Baksha R et al., 2005).

\section{Materials and methods:- \\ Collection of explants}

The explants for the research studies were identified as Aloe barbadensis by Ministry of Environment, Forest and Climate Change, Botanival Survey of India. After the authorized identification, they were maintained in the Green house at Genewin Biotech, Hosur for further use in the Research study.

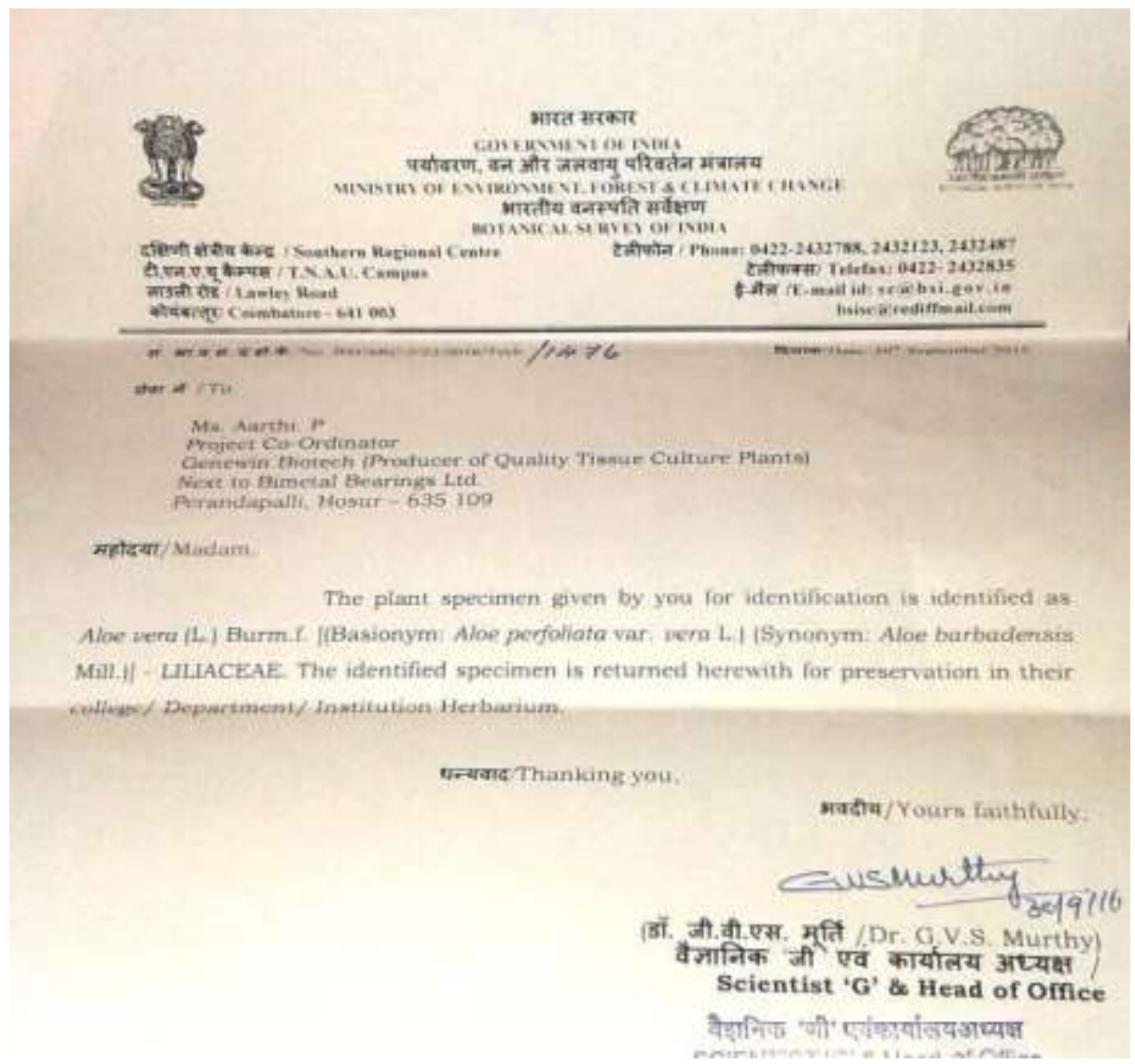

Fig 1:- Identification Of Species.

\section{Preparation Of Explants :-}

The explants were collected based on the maturity of the leaves from the healthy Aloe vera plant. The New emerging leaves were selected as explants. The collected explants were brought to the production laboratory and washed thoroughly in running tap water for $10 \mathrm{~min}$ in order to eliminate the muddy dust particles from the explants (Baksha R et al., 2005). 

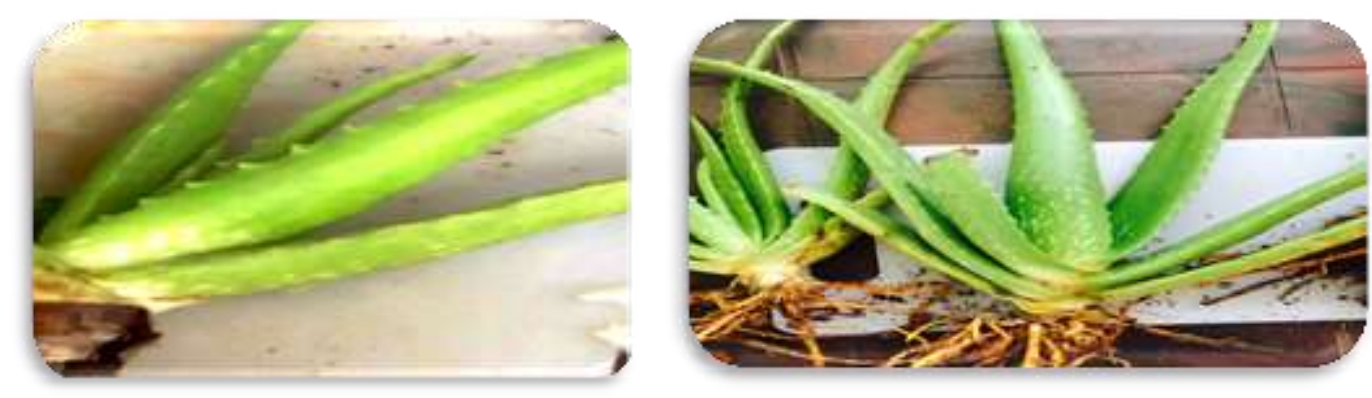

Fig 2:- Explant Preparation

\section{Explants Sterilization:-}

The new bud explants were soaked in antifungal and antibacterial solution, carbendazim $(0.1 \%)$ and streptocycline $(0.1 \%)$ for 15 minutes. The sterilization is followed by wiping of leaves very carefully using $70 \%$ ethanol with sterilized cotton. Finally, explants were treated using detergent, Polysorbate 20 for 20 minutes. The explants were washed with sterile water three times to ensure the complete removal of foam.

The explants then ready for layer by layer removal for the initiation of shoot regeneration. The collected explants were soaked in $10 \%$ Sodium hypochlorite for $40 \mathrm{~min}$ and the first layer is removed. After the removal of first layer, the explants were again soaked in $10 \% \mathrm{NaOCl}$ for $40 \mathrm{~min}$ and the second layer was removed.

The sterilization is further carried out inside laminar air flow chamber using surface sterilant and 2 sets of experiments were performed.

SET 1: Mercuric chloride $(0.1 \%)$ as surface sterilant for 3, 5, 7, $9 \mathrm{~min}$. The explant were removed from the mercuric chloride solution and washed with sterile water thrice to eliminate the toxic effects of Mercuric chloride.

SET 2: Sodium hypochlorite $(\mathrm{NaOCl})$ as surface sterilant at various concentrations such as $10 \%, 20 \%$ and $30 \%$ for 20 min.

Bud break was recorded in each trial in 3- 4 weeks (Diwakar Aggarwal).

\section{Mortality Rate:-}

Mortality rate, or death rate, is a measure of the number of deaths (in general, or due to a specific cause) in a particular population, scaled to the size of that population, per unit of time.

The Mortality rate was calculated by

$$
\% \text { Mortality }=\text { Explants contaminated } / \text { Total no of Explants } \quad \text { X } 100
$$
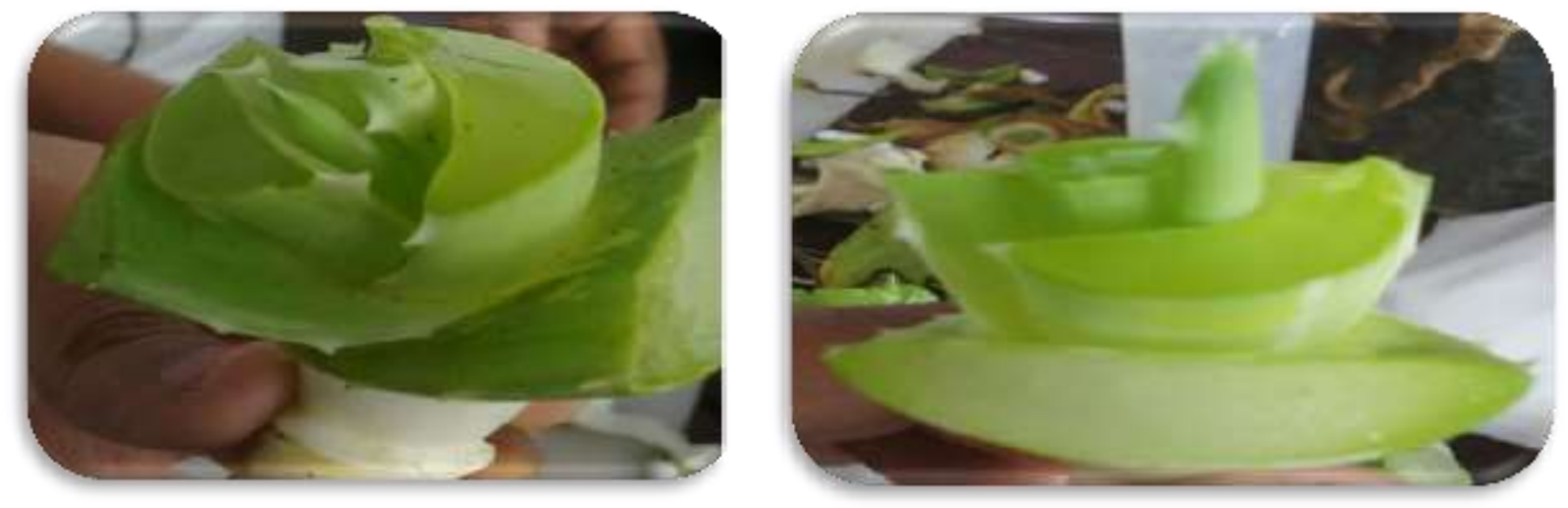

Fig 3:- Explant Selection

\section{Explants Initiation:-}

Initiation stage gives rise to regeneration of new shoots from the selected explants in 15 days. The growth was frequently monitored every week and recorded. The surface sterilized explants were inoculated in following MS basal media treatments + Sucrose $3 \%$ with various growth regulator concentrations.

AVIM 1: $6 \mathrm{BAP}-0.5 \mathrm{mg} / \mathrm{l}+\mathrm{NAA}-0.1 \mathrm{mg} / \mathrm{l}$ 
AVIM 2: 6BAP - $1 \mathrm{mg} / \mathrm{l}+\mathrm{NAA}-0.1 \mathrm{mg} / \mathrm{l}$

AVIM 3: 6BAP - $1.5 \mathrm{mg} / \mathrm{l}+\mathrm{NAA}-0.1 \mathrm{mg} / \mathrm{l}$

AVIM 4: 6BAP - $2 \mathrm{mg} / \mathrm{l}+\mathrm{NAA}-0.1 \mathrm{mg} / \mathrm{l}$

AVIM 5: 6BAP - $2.5 \mathrm{mg} / \mathrm{l}+\mathrm{NAA}-0.1 \mathrm{mg} / \mathrm{l}$

Before inoculation, the outer scaly leaves like thorns were removed aseptically for the better performance of the explants. The explants were placed in the prepared media; the mean parameters were calculated. The inoculated jars were incubated (Hans B. Juneby).

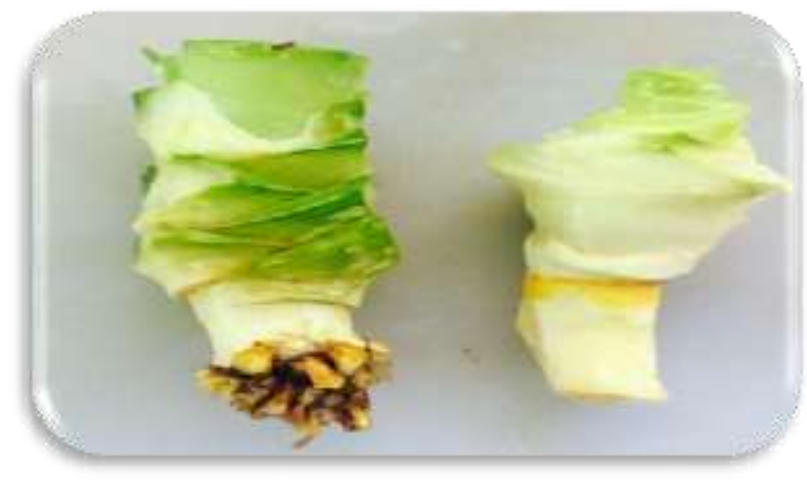

Fig 4:- Explant Initiation

\section{Culture Conditions:-}

The explants are subjected under light intensity for 10-12 h in the growth room. Photoperiod provided by cool white fluorescent lamps of 1500-3000 lux, temperature of about $25 \pm 2{ }^{\circ} \mathrm{C}$ and humidity of $35-40 \%$. The observation will be recorded after 4-5 weeks.

\section{Results and discussion:-}

Effect of surface sterilization:-

\begin{tabular}{|c|c|c|c|c|}
\hline $\begin{array}{lc}\text { Treatment } & \text { Of } \\
\text { Mercuric Chloride }(\%)\end{array}$ & $\begin{array}{l}\text { No Of Explants } \\
\text { Taken }\end{array}$ & Mortality Rate (\%) & $\begin{array}{l}\text { No Of Explants Not } \\
\text { Responded (Nos) }\end{array}$ & $\begin{array}{l}\text { Bud Break } \\
(\%)\end{array}$ \\
\hline $0.1 \% \mathrm{Hgcl}_{2}-3 \mathrm{Min}$ & \multirow{4}{*}{ Pans } & $86 \pm 2.3$ & 12 & $2 \pm 1.2$ \\
\hline $0.1 \% \mathrm{Hgcl}_{2}-5 \mathrm{Min}$ & & $20 \pm 3.5$ & 66 & $14 \pm 0.3$ \\
\hline $0.1 \% \mathrm{Hgcl}_{2}-7 \mathrm{Min}$ & & $51 \pm 3.3$ & 48 & $1 \pm 3.2$ \\
\hline $0.1 \% \mathrm{Hgcl}_{2}-9 \mathrm{Min}$ & & $47 \pm 4.1$ & 53 & 0 \\
\hline
\end{tabular}

Table-1: Effects of surface sterilization

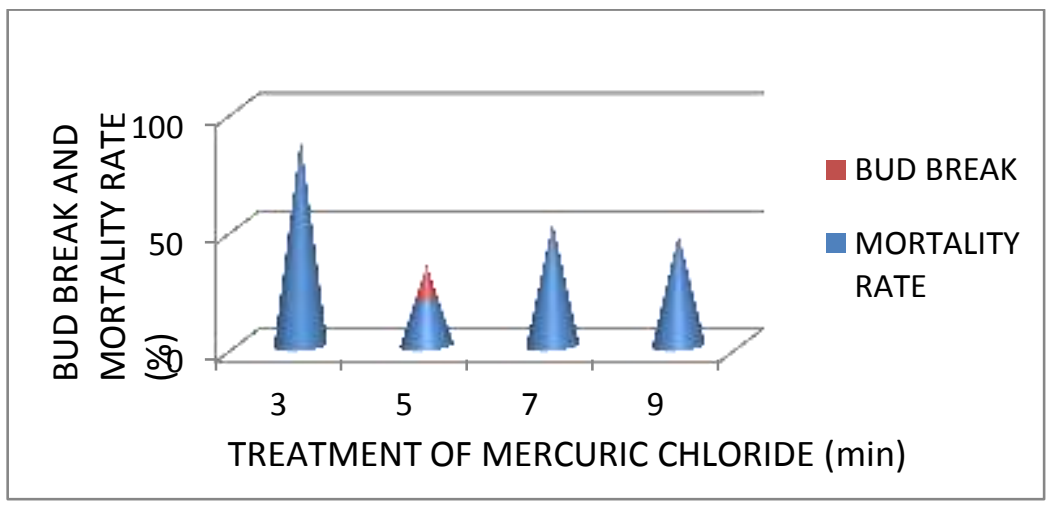

Graph 1:- Mortality rate with Mercuric chloride 

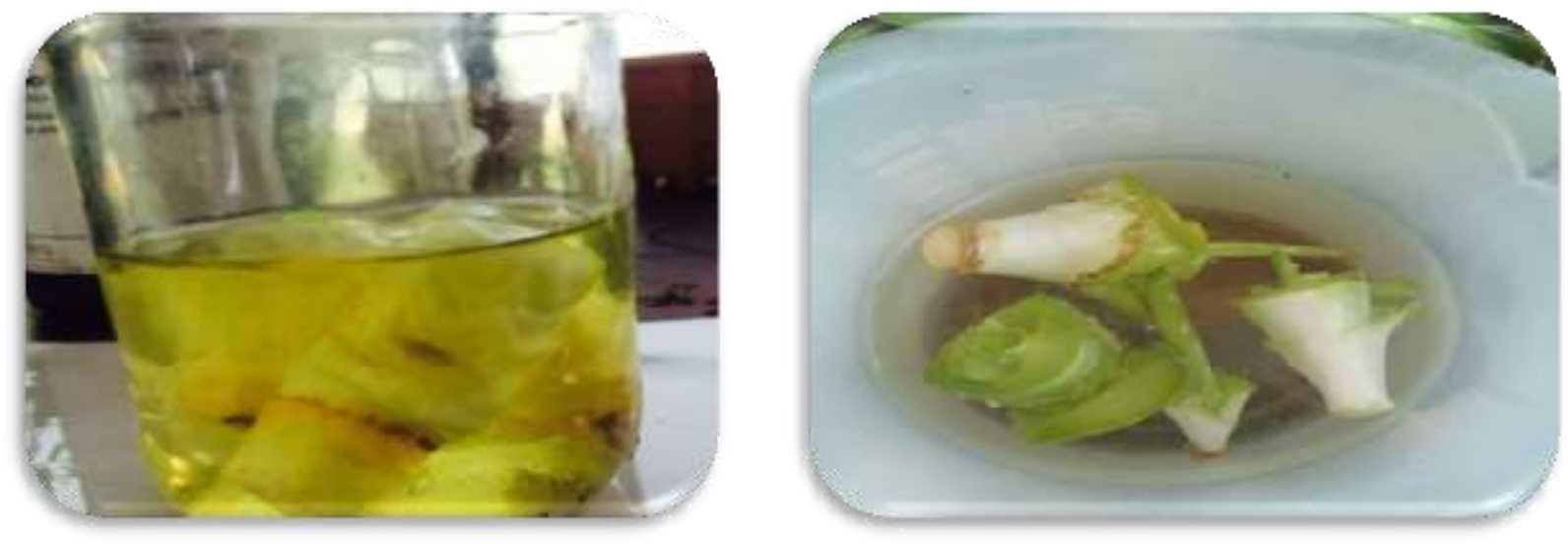

Fig 5:- Surface Sterilization

Majority of the explants survived after treatment when they were exposed to mercuric chloride for about 5 min. Treatment with $3 \mathrm{~min}$ were found with more mortality of the explants whereas treatment for more than 5 min found to have mortality but comparatively less but the explants were non-responsive (Zarreen badar et al., 2013).

\begin{tabular}{|l|l|l|l|l|}
\hline $\begin{array}{l}\text { TREATMENT OF } \\
\text { SODIUM } \\
\text { HYPOCHLORITE (\%) }\end{array}$ & $\begin{array}{l}\text { NO OF EXPLANTS } \\
\text { TAKEN }\end{array}$ & $\begin{array}{l}\text { MORTALITY } \\
\text { RATE (\%) }\end{array}$ & $\begin{array}{l}\text { NO OF } \\
\text { EXPLANTS NOT } \\
\text { RESPONDED }\end{array}$ & $\begin{array}{l}\text { BUD } \\
\text { BREAK } \\
(\%)\end{array}$ \\
\hline 10 & \multirow{2}{*}{20} & $34 \pm 3.2$ & 3 & $63 \pm 5.4$ \\
\hline 20 & & $41 \pm 2.7$ & 17 & $42 \pm 2.8$ \\
\cline { 3 - 5 } & & $59 \pm 1.4$ & 20 & $21 \pm 1.5$ \\
\hline
\end{tabular}

Table-2: Mortality rate of shoots

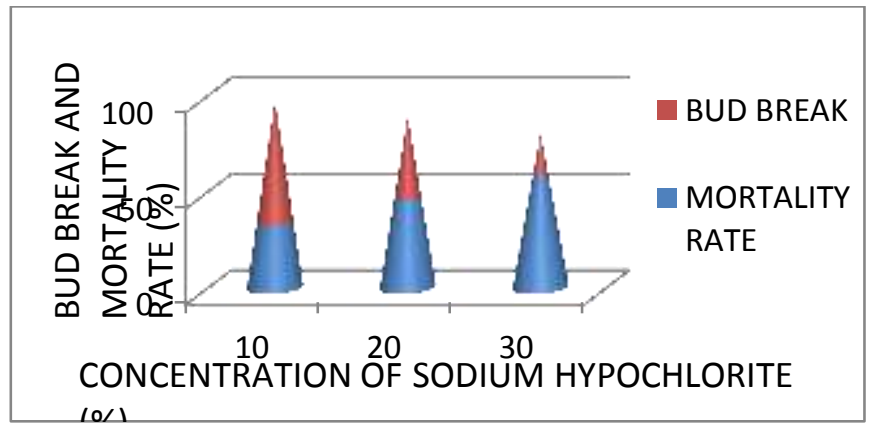

Graph 2:- Bud break and Mortality rate

Majority of the explants survived after treatment when they were exposed to Sodium hypochlorite at $10 \%$ and the success rate was found as 63\%. Other concentrations of Sodium hypochlorite showed success rate of bud break of about $42 \%$ and $21 \%$ and less percentage of explants also were non responsive (Bradley, 1992).

Initiation for shoot regeneration:-

\begin{tabular}{|l|l|l|l|l|}
\hline TRIAL MEDIA & $\begin{array}{l}\text { NO.OF EXPLANTS } \\
\text { TAKEN }\end{array}$ & $\begin{array}{l}\text { NO.OF } \\
\text { EXPLANTS } \\
\text { RAISED } \\
\text { SHOOTS }\end{array}$ & $\begin{array}{l}\text { MEAN HEIGHT } \\
\text { OF SHOOTS (cm) }\end{array}$ & $\begin{array}{l}\text { MEAN } \\
\text { INITIATION } \\
\text { RESPONSE }\end{array}$ \\
\hline AVIM1 & \multirow{3}{*}{20} & 9.3 & 0.8 & 27 \\
\hline AVIM2 & 10 & 0.92 & 31 \\
\hline AVIM3 & 16 & 2.1 & 84 \\
\hline AVIM4 & & 5.1 & 0.77 & 11 \\
\hline AVIM5 & 4.2 & 0.51 & 9 \\
\hline
\end{tabular}

Table 3:- Initiation for shoot regeneration. 


\section{Key: AVIM - Aloe vera Initiation Media.}

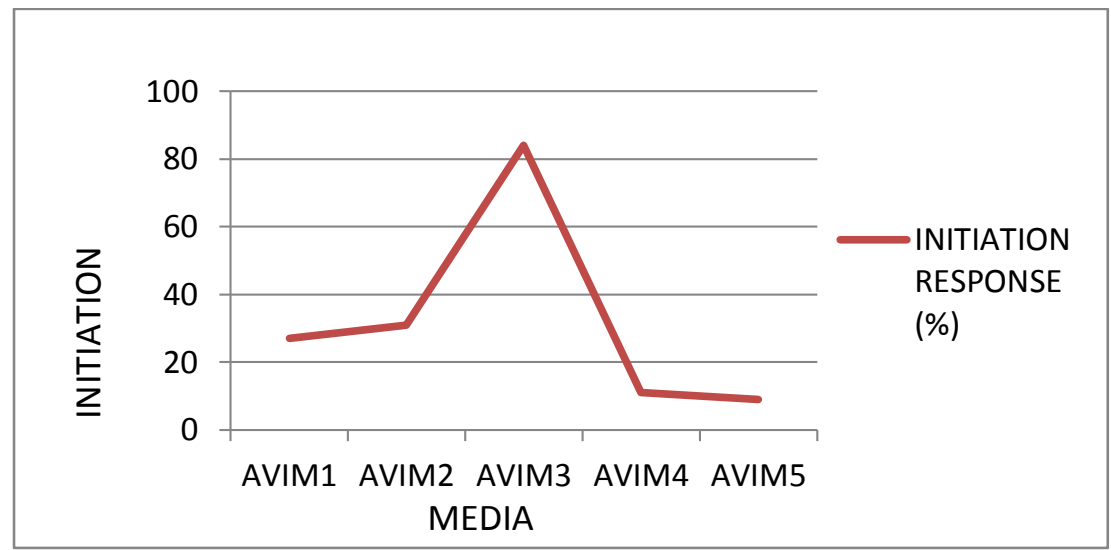

Graph 3:- Initial response.
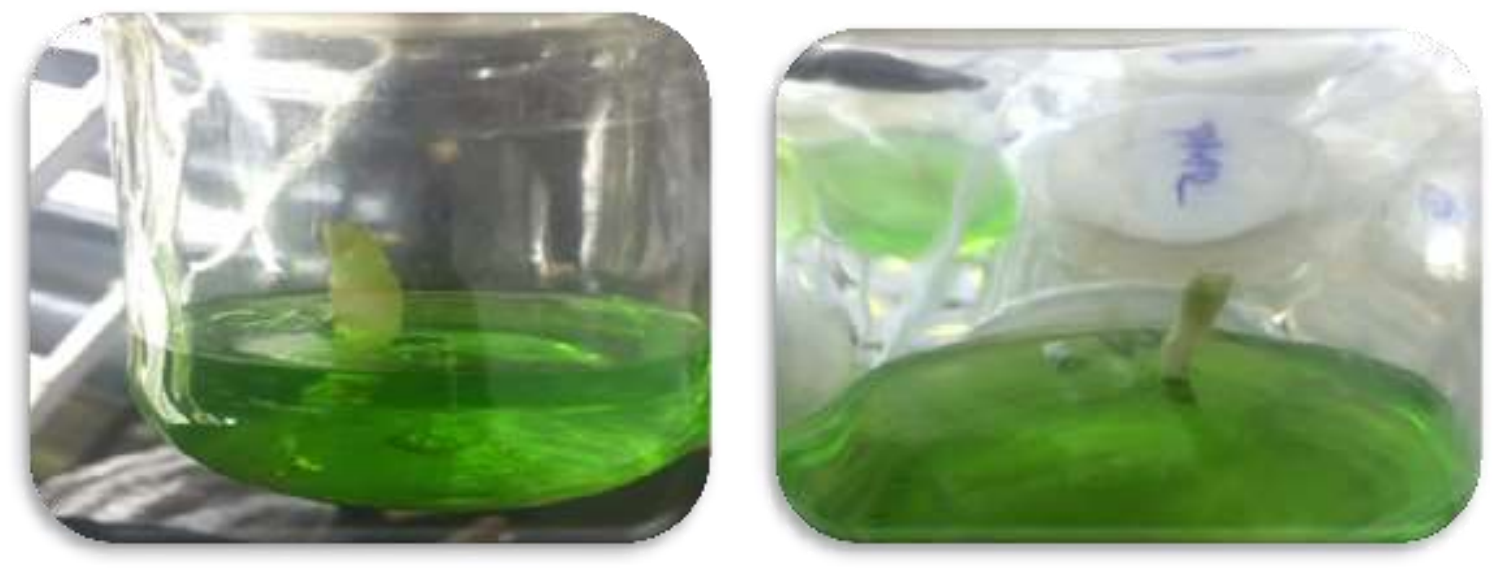

Fig 6:- Initial Shoot Response

Initiation of nodal response was found as $84 \%$ which trailed with the combination of $6 \mathrm{BAP}-1.5 \mathrm{mg} / \mathrm{l}+0.1 \mathrm{mg} / \mathrm{l}$ with mean height of $2.1 \mathrm{~cm}$. other media trials with $6 \mathrm{BAP}$ of about $0.5,1,2 \mathrm{mg} / \mathrm{l}$ were found with lesser shoot regeneration and less shoot height and further transferred to multiplication stage (Zarreen badar et al., 2013).

\section{Conclusion:-}

This study is evident that the Aloe vera can be rapidly produced through Tissue culture. It is identified that the commercial propagation could not meet the high demands of medicinal Aloe vera, plant tissue culture proved to be a promising technology in the production of novel improved plant species with higher Quality and Quantity. Regeneration from the explants using various growth regulators were trialed and the best regeneration response was recorded which will be further transferred for the multiplication.

\section{Acknowledgement:-}

The authors record their sincere thanks to Dr. V. Palani, Managing Director, Founder and Managing Director of Genewin Biotech, Hosur for providing Technical support and necessary laboratory facilities to carry out this work in their DBT certified laboratory successfully.

\section{References:-}

1. Dwivedi, N.K., Indiradevi, A., Asha, K.I., Asokan Nair, R. and Suma A. (2014): A protocol for micropropagation of Aloe vera L. (Indian Aloe) - a miracle plant. Res. Biotechnol., 5(1): 1-5.

2. Eufrocinio C. Marfori and Aubrey B. Malasa. (2005): Tissue Culture for the Rapid Clonal Propagation of Aloe barbadensis Miller. Philipp. Agric. Sci., 88( 2). 
3. Baksha, R., Miskat Ara Akhter Jahan, Rahima Khatun and John Liton Munshi. (2005): Micropropagation of Aloe barbadensis Mill. Through In vitro Culture of Shoot tip Explants. Plant Tissue Cult. Biotechnol., 15(2): 121-126.

4. Diwakar Aggarwal, Tissue culture of a medicinal plant - Aloe vera L.

5. Hans B. Juneby. Aloe barbadensis a legendary medicinal plant. Department of Medicinal Chemistry, Uppsala University, Sweden.

6. Zarreen Badar, Saifullah Khan, Saifullah, Kashif Ali, Syed Ghulam Musharraf and Muhammad Iqbal Choudhary. (2013): In vitro and biotransformational studies of Aloe barbadensis mill. Pak. J. Bot. Sci., 46(2): 679-685.

7. Bradley, P.R., (1992): British Herbal Compendium, British Herbal Medicine Association: Bournemouth, UK. 